that Governor Phillip took with him from Brazil some prickly pear plants, for the sake of the cochineal insects which infested them. These insects produced the scarlet dye used for the military uniforms of those days. Unfortunately, the insects appear to have perished during the voyage; thus the prickly pear, freed from its insect control, developed eventually into Australia's foremost plant pest.

At that time, oil of peppermint was a much prized specific ; for in the first issue of the Glasgow Advertiser, dated January 27,1783 , it is stated in an advertise. ment that "this elegant preparation", sold by J. Gillies, bookseller, above the Cross, Glasgow, gives immediate relief "in Gouty and Cholicky Pains in the Stomach and Bowels, Low Headachs, and all Disorders arising from wind". Dr. White, being short of this oil, found a very efficient substitute in the essential oil distilled from a certain eucalypt growing around Port Jackson-now known as the Sydney peppermint, or Eucalyptus piperita. This is the first recorded instance of the distillation of a eucalyptus oil.

Many years later, in 1900, the Australian chemist, H. G. Smith, isolated the peppermint ketone imparting the characteristic odour to this oil, and called it piperitone. There are about three hundred species of eucalyptus, each kind-as shown by H. G. Smith and R. T. Baker-producing its own characteristic leaf oil : of these more than twenty secrete piperitone. It was then found that, by hydrogenation and dehydrogenation, piperitone could be changed into menthols and thymol, respectively, so that it has become a commercially valuable substance.

Eucalyptus piperitone is invariably a 'left-handed' substance. Soon after Prof. Read became associated with Mr. Smith at Sydney, in 1920, Prof. J. L. Simonsen, working independently at Dehra Dun, in India, discovered 'right-handed' piperitone in the oil of the Indian grass, Andropogon Jwarancusa. These two piperitones, of the northern and southern hemispheres, are identical, except that their molecules are related as object and mirror images.

One interesting result of later researches, carried out at St. Andrews, has led to a way of proceeding, by laboratory processes, from the 'left-handed' Australian piperitone to the 'right-handed' Indian piperitone. It has also been found possible by means of a complicated network of delicate reactions to utilise piperitone as a source of any one of the four series of menthols. Each of the four kinds of menthol exists in a 'right'- and 'left'-handed form, and methods have been devised for producing the 'right-handed' form of ordinary 'mint camphor', which always is 'left-handed' in Nature.

\section{Crossing-Over of Sex Factors in Lebistes}

W HILE the validity of the sex-chromosome mechanism in relation to sex determination is generally recognised, yet it has become clear from the work of Goldschmidt on Lymantria, Winge on Lebistes, and various other investigations in which intersexes and the crossing-over of sex factors occur, that genes influencing the sex towards maleness or femaleness are also found in the autosomes. Bridges' conception of genic balance applies to many characters, including sex, and it is necessary to suppose that there are many factors in all the chromosomes, some of which tend towards maleness and others towards the female condition. Various divergent views regarding the distribution of such genes in the $X$ and $Y$ and the autosomes are at present held.

In the little fish, Lebistes, in which there is a series of colour patterns inherited through the $Y$-chromosome from father to son, Winge has shown also that the $X$-chromosomes may be altered into autosomes, so that sex-linked genes are inherited as ordinary Mendelian differences. By selecting masculine autosomal genes, $X X$ males were obtained, and by backcrossing a race was produced in which both the males and females were $X X$ in composition and the $Y$ chromosome type of inheritance had been eliminated.

In a recent paper $(C . R$. Lab. Carlsberg, Série Physiol., 21, No. 1) Winge has carried the subject of sexual balance further. Probably in these fishes, as in pigeons, the difference between the sexes is small, so that the balance of the sex genes is easily upset. This is further shown by the fact that certain matings gave practically only females in winter but equal numbers of the sexes in spring. Nevertheless, conspicuous intersexes seldom appeared. Normally, females show no trace of the colour genes which are transmitted by the males in the $Y$-chromosome, but occasional females appear which show a trace of the male pattern and probably have several masculine genes. In a cross involving the maculatus and lineatus races, $7 X Y$ females appeared having the maculatus spot. Crossed with $X Y$ males they gave, as predicated, 3 males : 1 female. Among these were fertile $Y Y$ males which, when crossed with normal females, gave only male offspring.

There are no unequal pairs of chromosomes in Lebistes, so the $X$ and $Y$ must be of equal size. Among other conclusions reached are that all the genes in $X$ are able to cross over to $Y$, and that the $Y$ contains at one end a specifie male-determining gene which is at the same time a gene for colour pattern. The $X$ lacks this gene, but whether it possesses an allelomorphic feminine gene is undecided.

R.R. G.

\section{University and Educational Intelligence}

Aberdeen.-The honorary degree of LL.D. has been conferred on the following, among others : Prof. E. V. Appleton, Wheatstone professor of physics, King's College, London ; Mr. W. H. Buckler, engaged in archæological work in Asia Minor; Lieut.-Col. A. T. Gage, formerly director of the Botanical Survey of India and superintendent of the Royal Botanic Gardens, Calcutta; Dr. J. C. G. Ledingham, professor of bacteriology, University of London, and director of the Lister Institute, London.

EDINBURGH.-A gift of $£ 10,000$ has been received from Mr. J. Albert Thomson for the purpose of establishing a commercial laboratory in the University. This will provide for the immediate requirements in staff and equipment for a laboratory providing the approved methods of training for students for the commerce degree, so that those who aspire to the higher positions in industry shall have an intimate working knowledge of all up-to-date office machinery and appliances..

London.-The County Borough Council of West Ham has decided to make a grant of $£ 2,500$, payable over five years, towards the cost of the erection of the new buildings in Bloomsbury. The Worshipful Company of Plumbers has made a donation towards the cost of the Ceremonial Hall to be built on the Bloomsbury site. 
ST. ANDREws. - The University Court has recorded a Minute on the occasion of the jubilee of the appointment of Prof. D'Arcy W. Thompson to the University (Nature, 135, 59, Jan. 12, 1935). Tribute is paid to his outstanding worth and ability, not only in his own department of natural history but also in other departments of literary and scientific knowledge. His election to the presidency of the Classical Association testified to his knowledge of and interest in the ancient languages and literatures of Greece and Rome ; his election as an honorary member and as president of the Edinburgh Mathematical Society in recognition of his pioneer work in the application of mathematical methods to biological studies was a guarantee of mathematical ability of no mean order ; and his work as adviser to the Fishery Board for Scotland, and as a delegate to the Bering Sea Fisheries Conference and to the North Sea Conference indicated his international reputation as a scientific administrator.

Moscow State University will hold a summer school from July 16 until August 25. Instruction will be in the English language by an all-Soviet staff in twelve courses of thirty hours each, with occasional addresses by prominent Soviet officials. The subjects of the courses include : Russian language (advanced), Russian literature, Russian arts, Russian education, Russian technology, Russian economics, Russian geography and Russian history (of the Soviet Union), ad. ministration of justice, public health and medicine, and the philosophy of dialectical materialism. The students will also be able to choose one of six specially organised tours. Last year's summer school enrolled 212 students.

UNIVERSITY COLLEGE, London, continues to attract students from abroad in large numbers. The recently issued annual report shows that of a total of 3,231 students enrolled in 1933-34, no fewer than 744, or 23 per cent, were from countries outside the British Isles, namely, 304 from other parts of the Empire and 440 from some forty foreign countries. Among European countries Germany contributed 102, France 35 , Switzerland 26 and Holland 19 students, while India was represented by 157 , the United States of America by 45 , South Africa by 31, Palestine and Australia each by 26 . In the course of the year, the quinquennial visitation by members of the University Grants Committee took place, and from the summary of developments of the years 1930-35 prepared for presentation to the Commissioners, a number of interesting paragraphs have been reproduced in the report. One of these relates to the great change that has taken place in the proportion between full-time and part-time students, the former having increased almost continuously since 1925-26 while the latter have diminished from nearly 1,600 to less than 1,100 . The number of full-time postgraduate and research students has risen during the past ten years from 168 to 255 . Several departments of the College were enabled, through the generosity of various benefactors, to offer hospitality during the past year to a number of scholars exiled from their homes in Germany, among them the distinguished chemist Prof. H. Freundlich. Annexed to the report is an address by Sir Josiah Stamp, delivered by him as Special Visitor on the occasion of the annual assembly of the Faculties: the subject is "The Management of Mind".

\section{Science News a Century Ago}

\section{Lyell and Mantell}

On April 13, 1835, Lyell wrote to Mantell : "I have been getting Dinkel to figure for me some fossil eggs of a turtle, found in the island of Ascension, imbedded in a hard rock something like that of Guadaloupe which contains the human skeleton. It is clear that the eggs were nearly hatched at the time when they perished for the bones of the young turtle are seen in the interior with their shape fully de. veloped. .. . On my showing the specimen containing seven eggs to Owen, of the College of Surgeons, he remarked to me that they were hollow, whereas the bones of reptiles want the medullary cavity. Struck with this remark, and with the extreme hollowness of the bones, only to be compared to that of some Tilgate specimens which you have often shown me, I got Owen this morning to dissect for me a young turtle, not a foetus, but so young that the mark of the attachment of the yolk was still a large opening. He immediately showed me that the bones were not hollow, though we both remarked that the outside looked harder than the interior. Owen has promised to get me a set of very young turtle's bones from the Zoological Gardens, and I am persuaded it will clear up a number of your difficulties."

\section{The Zoological Gardens}

"The Commissioners of Woods and Forests," said The Times on April 14, 1835, "have recently granted to the members belonging to the Zoological Gardens, in the Regent's Park, an extensive increase of land consisting of 10 acres, on the south side of the Park, which is now railed in. Immediately an immense number of workmen of various denominations will be employed in levelling the ground, laying out, and planting elegant shrubberies; erecting superb habitations for various beasts and birds, which will be placed in them with all possible speed, from the society's collection at Kingston-on-Thames, where they have an immense farm. On the completion of the intended improvements, these gardens will present to the public the most superb promenades in England, the whole of which will be completed in a few weeks. Since the commencement of the warm weather, the whole of the beasts and birds which were of tender habits have been removed from the menagerie, where they have been kept during the winter months, and are now exhibited to the public. During the present spring, these gardens will be considerably more frequented, on account of the immediate opening of the Regent's Park to the public. The grand broad gravel walk which passes through the Park leads to the Zoological Gardens."

\section{The Franklin Institute}

The forty-fifth quarterly meeting of the Franklin Institute, Philadelphia, was held on April 16, 1835. Various donations of books were stated to have been received, some of these being from the Society for the Encouragement of Arts, Manufactures and Commerce of London, and others from Faraday. In the report of the Board of Managers, it was said that "The Lectures of the Institute were closed on the 25th March last ; the large number of the class, and the regular attendance during the season, clearly evince the interest taken by the members and the 